\title{
The Tibet Protests of Spring 2008
}

Conflict between the Nation and the State

\section{Robert Barnett}

\section{(2) OpenEdition}

\section{Journals}

Édition électronique

URL : http://journals.openedition.org/chinaperspectives/4836

DOI : 10.4000/chinaperspectives.4836

ISSN : 1996-4617

Éditeur

Centre d'étude français sur la Chine contemporaine

Édition imprimée

Date de publication : 1 septembre 2009

Pagination : 6-23

ISSN : 2070-3449

Référence électronique

Robert Barnett, "The Tibet Protests of Spring 2008 », China Perspectives [En ligne], 2009/3 | 2009, mis en ligne le 01 septembre 2012, consulté le 28 octobre 2019. URL : http://journals.openedition.org/ chinaperspectives/4836; DOI : 10.4000/chinaperspectives.4836

(C) All rights reserved 
(1)

The Tibet Protests

\title{
of Spring, 2008
}

\author{
Conflict between the Nation and the State
}

Preliminary assessment of 95 of the 150 or more protests in Tibetan areas in the spring of 2008 suggests that they were far more widespread than during previous unrest, and also that there was greater involvement of laypeople, farmers, nomads, and students than in the past. It argues that the struggle in China and elsewhere over representation of the unrest has been dominated by the question of violence, with little attention paid to policy questions and social issues. This paper outlines the basic concepts that underlie that debate and summarises the historical factors that might have led to protest.

\section{ROBERT BARNETT}

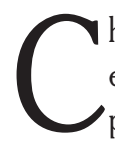
hinese governments have only ever tried twice to exercise direct rule in Tibet. Each attempt has been primarily a military operation and has been marked by fierce and recurrent resistance. The first attempt, a brief occupation of Lhasa by a Chinese army in 1910-12, failed after months of street fighting by Tibetan soldiers. That period of direct rule led to exile for the Tibetan leadership, created a crisis of identity for the nation, and caused deep bitterness among Tibetans towards those members of the elite who were seen as collaborators, though it also triggered a movement intent on modernisation. The second Chinese attempt at direct rule is still underway, has had very similar results, and continues to meet considerable resistance.

China reacquired control of Tibetan territory in 1950 and nine years later finally replaced the traditional Tibetan government and began its second attempt at direct rule. Its management of Tibet saw three major waves of opposition in the first 20 years: those of 1956-1958 in Eastern Tibet, 1959 in Lhasa, and 1969 in Nyemo and other rural areas, as well as guerrilla attacks by exiles based in Nepal from 1960 until 1974. Those episodes consisted largely of armed revolts or attacks by unofficial armies, village-level bands, or guerrilla forces. Since the death of Mao in 1976, there have been consistent efforts toward the liberalisation of Chinese society, with much greater tolerance of diversity, religion, and travel. Tibetan protest under these conditions has consisted mainly of street protests, most prominently the four major demonstrations that took place between October 1987 and March 1989, the long series of smaller demonstrations from 1989 to 1996, and the protests of March and April 2008, which are still continuing. The two major waves of protest - those of March 1989 and March 2008 - led to responses that were primarily military: 13 months of martial law in Lhasa from March 1989, and 15 months of paramilitary presence in the streets of Lhasa and other Tibetan areas from March 2008 until the time of writing this article (late May 2009), with no sign of it being lifted.

The waves of protest in Tibet in the post-1979 era were not a reaction to doctrinaire communism. They came well after China had started to do everything that the Maoist regime had failed to do - improving the grassroots economy, opening up to the outside world, allowing some religious practice, celebrating cultural diversity, and encouraging some degree of intellectual life. Tibetan protests in this new, reformist China raised difficult questions. They differed from the atomised and economy-driven protests typical of mainland China - they were multiple actions taken by members of a single nationality with shared values, and they were directed against the state's right to rule these areas. For some, they appeared to be the opportunistic pursuit of local advantage in China's new prosperity, while others saw them as invoking for China's leaders the spectre of legitimacy failure among their non-Chinese subjects. Whichever view is taken, these cycles of unrest raised critical questions about the modern China project: What does it offer? Can it deal with difference? Whom does it include?

The 2008 unrest in Tibet had significant political impact. It cemented an international perception of China as authoritarian at a moment when it seemed about to step beyond that at the Beijing Olympics that August; it propelled the Tibet issue to near the top of the agenda in Sino-US and Sino-European relations; and it led to China dealing with Europe primarily through an 
interdiction on its handling of Tibetan issues. It also led to a major reassertion of military or paramilitary presence on the ground in all Tibetan areas, a display of power that must have had negative impact on local perceptions of the Chinese state. The Tibetan unrest, coupled with the protests over the Olympic torch relays abroad, also changed the way politics is done and thought about in China. The intense attacks that emerged in both official and unofficial media in China against foreign representations of the 2008 events were not new in themselves - for decades if not centuries, political acts by Tibetans have been reshaped to fit starkly conflicting explanations by their neighbours and other interested parties. But these were the first major Tibetan protests to occur in the internet age, and they impelled young Chinese, the so-called fenqing or "angry youth," to deploy new technologies in inventive ways in their efforts to recover control of discourse for the Chinese nation from the international or Western handling of this issue.

In so doing, the Chinese activists, both at home and abroad, created a new alliance of Chinese intellectuals with the state and pushed the internal debate, and perhaps Party and governmental policy, towards increasingly polarised positions. These new positions in turn led to a change in political perception within Tibet, where increasingly the socialist model of negotiation between theoretically equal ethnic groups is being replaced by a model of racial antagonism of a type associated with colonial administrations. A similar change seems to have been taking place among policy-makers and commentators in China who deal with Tibet. Among Tibetans within China, views are likely effected by changes on the ground, such as increased restrictions, detentions, and military presence, but the changes in China as a whole are driven by representations - shifts in rhetoric, the media and public argument - producing one of the critical asymmetries that I discuss in this paper.

The difficulty of carrying out research in Tibetan areas means that the paper does not discuss what normally should be the primary issue in any political or social interpretation - the study of the thinking and experience of participants. ${ }^{(1)}$ Instead I look first at what is known of events in the spring of 2008 and assess what aspects of these might have seemed most important for political leaders and policy analysts in China. Secondly, I look at the conflict over the representation of these events and at the dispute among outside players - Chinese, exile, Western, and so on - over how these events should be interpreted and manipulated.

The focus of the paper is on events within China rather than on the exile or international arenas. As with any such study, all the data presented here concerning events in Tibet are provisional and are presented as general indicators only, since no definitive ground studies have been done or are likely to come to light. Similarly, terms such as Chinese, $\mathrm{Ti}$ betan, and Western are used in their most conventional sense as guideline indicators only, since each group inevitably contains a vast array of different thoughts, perceptions, attitudes, and interests in their defence of either the nation (a closely-bound community "united by factors such as common descent, language, culture, history, or occupation of the same territory, so as to form a distinct people," according to the Oxford English Dictionary) or the state ("the political organization which is the basis of civil government," ibid.).

\section{The pattern of protest}

In terms of information flow, the unrest of 2008 differed from any previous phase of protest in Tibet. Few if any $\mathrm{Ti}_{\mathrm{i}}$ betans were able to escape from Tibet in the 20 years after the Dalai Lama fled in 1959, but since the early 1980s, about 2,000 Tibetans a year have travelled from Tibet to setthe in India or the West, creating social networks that link them with relatives or friends in their home areas. When protests broke out in Lhasa in March 2008, the widespread use of cellphone and internet technology in Tibet allowed information to travel rapidly to these Tibetans who had newly arrived in exile, or directly to observers like myself.

Within China, an unofficial reporting network was set up in Beijing by the dissident Tibetan poet and blogger Woeser (also spelt Oeser; Tib. 'Od zer, Ch. Weise) and her husband, the Chinese writer Wang Lixiong, and scores of $\mathrm{Ti}_{\mathrm{i}}$ betan intellectuals forwarded news from their areas that were checked and published on her site, woeser.middleway.net. Most such reports were confirmed or elaborated by Western news correspondents in Beijing using contacts in the areas, ${ }^{(2)}$ by exile organisations based in India, or by the

1. Two important collections of opinions on the protests have been published privately in Tibet: (a) 'Gar rtse 'Jigs med (ed.), Btsan po'i snying stobs (Fierce Courage), Vol. 1, privately published (probably in Amdo, 2008), and (b) Northwest Nationalities University "The Eastern Conch Mountain" Editorial Group (Drolma, Kirti Kyab, Tsering Dorje et al.), Shar dung ri, (The Eastern Conch Mountain) - [English title: The Eastern Snow Mountain], Vol. 21 (2008). No place of publication or ISSN is given. About half the articles from this journal are published in English translation in A Great Mountain Burned By Fire: China's Crackdown In Tibet, ICT (International Campaign for Tibet), Washington, D.C., March 2009, pp. 70-105.

2. The most important Western sources in Beijing were The Times (London), which established its own network of sources, Associated Press, Reuters, The New York Times, Los Angeles Times and The Washington Post, all of which independently verified reports they received. Reports about some protests, such as those in Lhasa and Beijing, were received directly. 
Tibetan service of Radio Free Asia, a broadcasting station based in Washington DC and funded by the U.S. Congress, which based its reports on telephone conversations with witnesses. Exiles obtained and circulated on the internet unofficial footage of non-violent protests in Labrang monastery in Sangchu (Ch. Xiahe, Gansu), in Machu (Gansu), and, later, at Lutsa monastery in Mangra (Qinghai). Western news agencies obtained footage of incidents in Lhasa or themselves filmed protests in Labrang (The Guardian, 1 March) and at Amchok Bora in Sangchu (Steve Chao for Canadian TV, 15 March). For this survey I have only included reports that were confirmed by witnesses, or that had clearly separate sources containing details that indicated firsthand knowledge.

The process of verifying these reports was easier than in the past because of a new policy by the Chinese authorities that emerged at the beginning of the 2008 unrest of trying to gain control of representations: the official media almost always responded, usually within 12 hours, to any report in the foreign press of a Tibetan incident, usually confirming the outlines of the report but characterising it differently. In one or two cases where Tibetan protestors appeared in a bad light, such as a protest involving violence, the official media pre-empted Western publications. In two cases in Sichuan the reports stated that security forces had opened fire, but except in one account that was withdrawn the next day ${ }^{(3)}$ they did not admit to any killings of protestors. Footage of protests in Lhasa and southern Gansu on 14-16 March was broadcast on television in China, though only where it showed violence by protestors. ${ }^{(4)}$ Thus for the first time there are a significant number of official reports of Tibetan unrest, including rural incidents. These characterised protestors in negative terms, but in doing so confirmed initial reports collected by Woeser and others.

From cross-checking these reports it is clear that at least 95 separate protests took place in Tibetan areas within China in the three and a half weeks from 10 March to 5 April 2008. The full number of incidents is likely to have been at least 150, given the underreporting of incidents in remote villages and townships, particularly in Kanlho (Ch. Gannan, a Tibetan area in the south of Gansu province $\left.{ }^{(5)}\right)$.

These numbers seem small compared to the 80,000 or so protests that are said to take place in China each year, many of them rural disputes over land and corruption, often including violence, which are apparently not regarded as a major political challenge by the government or the Party. Why did the authorities treat the Tibetan events differently, as a threat requiring a coordinated, cross-regional military re- sponse? Some of the reasons are clear - the Tibetan protests had common objectives, showed signs of possible coordination, had national and religious dimensions, had foreign implications and support, and disputed the government's right to rule rather than excesses by particular local officials. Other factors are indicated by simple statistics. These were the first street protests, in the sense of explicit displays of opposition to Chinese rule, in Tibetan areas for some 12 years. Small incidents had taken place in the previous two years - a sit-down protest against religious restrictions staged within the monastery of Drepung in Lhasa in November 2005, a conflict among monks at Ganden monastery over a controversial religious cult in 2006, symbolic gestures about environmental and wildlife issues that same year, a protest about graduate unemployment in Lhasa also in 2006, flash-riots over ethnic conflicts in July 2007, and a symbolic repainting of the Dalai Lama's former residence to mark an award to him by the U.S. Congress in October 2007. But political street protests by Tibetans against Chinese rule, even small-scale incidents, had come to an end in 1996, apparently because the increasingly rapid responses of security forces (teams in plainclothes placed at readiness around the central temple, the main site for protests in Lhasa) and the severity of prison sentences for protestors (an average of around 6.5 years for any public protest, however brief) had made the practice no longer worthwhile for protesters, especially since news of such incidents rarely reached the outside world or attracted press attention. There

3. The authorities admitted to killing four Tibetan protestors in Ngaba on 16 March (see "URGENT: Four Rioters Shot Dead Sunday in Aba of SW China, Police sources," March 20 (Xinhua), accessible at http://www.highbeam.com/Search.aspx?q=\%22Four+ Rioters+Shot+Dead+Sunday+in+Aba+of+SW+China+Police+sources\%22). The statement was replaced without comment the following day by "Police: 4 rioters wounded in Aba of Sichuan," Xinhua, 21 March 2008 (see http://www.china.org.cn/200803/21/content_13190976.htm). The original report is no longer available on official Chinese websites.

4. See "The True Account of the Violent Events of Beating, Smashing, Looting and Burning in some Counties and Townships in Gannan Tibetan Autonomous Prefecture," a 20minute compilation in Chinese of videos showing rioting 14-18 March in Kanlho (Gannan, Southern Gansu) by Gannan TV and given to foreign journalists.

5. " 150 incidents of 'smashing, looting, beating and burning' had taken place between 10 March and 25 March in the Tibetan areas of Qinghai, Gansu and Sichuan provinces and the Tibet Autonomous Region," Li Bin and Li Yajie, "Inside Story of Dalai Clique's Manipulation of "Tibetan People's Uprising Movement," Xinhua, 1 April 2008. Cited in "China: Hundreds of Tibetan Detainees and Prisoners Unaccounted for," Human Rights Watch, 9 March 2009. The blog woeser.middleway.net (accessed 5 April 2008) cited an official newspaper in Sangchu (Ch. Xiahe) in Gansu as stating on 23 March 2008 that "the correspondent has learnt from the government of Gannan Tibetan Autonomous Prefecture in Gansu Province that during this incident 105 organizations which are directly subordinate to the county and city, 27 towns and 113 working units under the towns as well as 22 village committees were seriously affected." The International Campaign for Tibet, a U.S.-based advocacy group, gave a figure of 130 protests between 10 March and 22 June 2008 (Tibet at a Turning Point: The Spring Uprising and China's New Crackdown, International Campaign for Tibet, Washington, D.C, 6 August 2008, pp. 19-22) 
Figure 1. Map of Tibetan protests

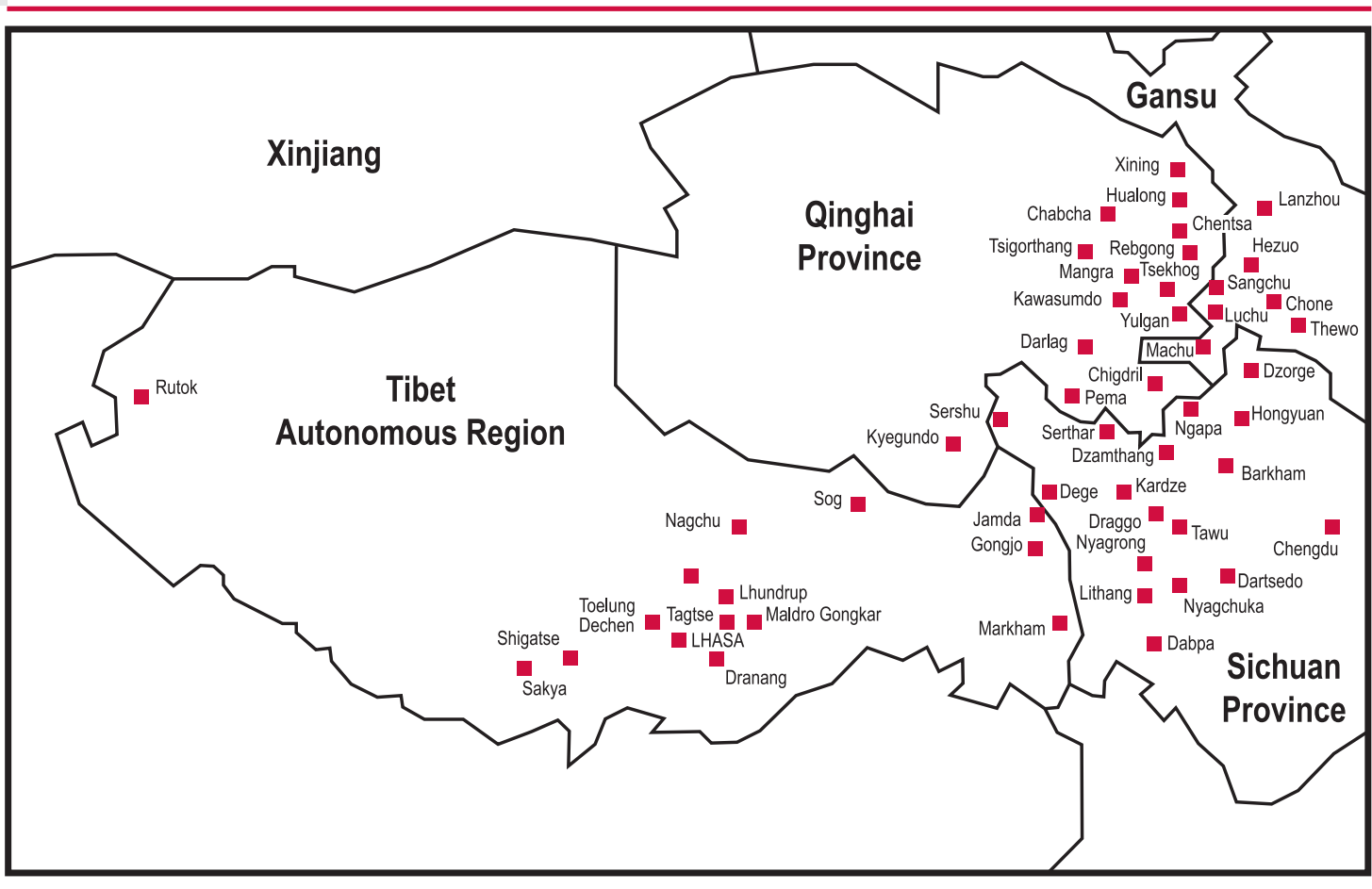

Squares and names indicate counties, towns or cities where protests took place from 10 March to 12 April 2008. Within a county there may have been numerous protests in different villages or monasteries. Courtesy of Robert Barnett and Tashi D. Lek.

had been no large-scale street protests in Lhasa explicitly against the government for 19 years.

In those years the economy had seen the most dramatic expansion in history, with double-digit growth in GDP in the TAR in each of the preceding 14 years, a result of a ferociously focused policy by Beijing of infrastructural development, GDP growth, and financial subsidies for the western areas of China and especially the TAR. In China, it seems that this was taken to mean that the Tibetan population was more contented. In addition, leaders in Tibetan areas were reporting back to Beijing, and to the public, that as a result of this economic progress and other factors, such as intensive political education, Tibetans were increasingly supportive of the regime and were no longer interested in the Dalai Lama or in opposition to the government. This practice of misreporting by local leaders, and especially the phenomenon of the centre believing such reports, is central to any analysis of Chinese handling of Tibetan issues. This centre-periphery informational asymmetry explains much of the disproportionate impact of the 2008 protests within China; if it had not encouraged misreporting of opinions in the area, the government would have long known that unrest was to be expected.
In any event, they appeared to refute the proposition, seemingly the basis of much Chinese policy towards nationalities since the late 1970s, that increased wealth brings increased social order and allegiance to the source of that wealth, the Chinese government and the Chinese Communist Party (CCP).

\section{The politics of geography}

The details of the protests indicate why these events had exceptional political significance for China's leaders. The incidents in the late 1980s had taken place mainly in Lhasa, whereas the new events covered much of the Tibetan plateau. Between 1987 and 1996, some 213 political protests were reported from Tibet, of which 160 were confirmed, ${ }^{(6)}$ but only 5 of these took place outside the TAR. In the 2008 wave, 22 of the 95 reported incidents took place in the TAR (including in some sparsely populated areas in

6. See "Demonstrations September 1987 to August 1992," Tibet Information Network Background Papers on Tibet - September 1992, Tibet Information Network, September 1992, and "Reported Demonstrations 1992-93: List," TIN News Compilation, October 1993 - Reports from Tibet 1992-3, Tibet Information Network, October 1993, p. 31. 
far west and north of the TAR), while 75 occurred in the eastern parts of the Tibetan plateau, either in the north-eastern region traditionally known as Amdo or in the eastern region known as Kham. In terms of current Chinese administrative areas, Qinghai saw at least 30 incidents, Sichuan had 23, and southern Gansu had 22. This means that among the five province-level administrative entities in China with $\mathrm{Ti}$ betan areas, only Yunnan did not have protests. The incidents at village or township level that have not yet been confirmed and so not included in these numbers were also in eastern $\mathrm{Ti}_{\mathrm{i}}$ betan areas, and the 40 or more incidents that have taken place since April 2008 have been in the east as well.

This is important not just because it shows that the area of demonstrated discontent was far wider than in the past. The Tibetan areas outside the TAR had much milder policies in the 1980s, such that they were sometimes described as functioning examples of nationality-state harmony even by Western journalists, and as effective examples of local autonomy and cultural respect. ${ }^{(7)}$ Only these areas had Tibetanmedium middle schools (there are none in the TAR), they had not been affected by the martial law provisions of 1989, and they had a much higher proportion of Tibetans in the local leadership, with apparently more devolved forms of administration. They had in general larger monasteries with less interference in religious practice, extensive publications in Tibetan, and dynamic cultural and intellectual activity in Tibetan language - Tibetan writers, poets, unofficial journals, publishers, film-makers, bloggers, and musicians flourished in these areas, dominating Tibetan cultural life. Every Tibetan knew that state controls, at least since the protests of 1987, were much more restrictive in the TAR than in the eastern areas, and fieldwork by foreign scholars is almost entirely confined to the eastern areas. Foreign tourists have not been able to enter the TAR legally as individuals since 1989, but all the eastern Tibetan areas were made open to individual foreigners, without any special permits, at least ten years ago. Common sense would have predicted a much higher level of satisfaction with China in the eastern Tibetan areas than in the TAR since the early 1980s, and a loss of that support signifies a serious shift in allegiance of Tibetan peoples in those areas.

There are other reasons that might have led Chinese policymakers to feel concern at the increased unrest in Kham and Amdo. Although the written language of those areas is almost identical with that of central Tibet, many of the spoken dialects are mutually incomprehensible. The social system before the Chinese take-over had been different: the large manorial estates owned by aristocrats were a feature of cen- tral Tibetan society that was not much known in the east. And historically, most of the eastern areas had not been ruled by Lhasa for centuries. In the early twentieth century, the Lhasa government briefly recovered control of parts of Kham, but eastern areas of Kham and the whole of Amdo had been not been controlled by Lhasa for at least two centuries. Although Lhasa had included in the 1913 Simla Convention its claim to having a special role or interest in these territories, when the PLA took over those areas during 1949 and 1950, Lhasa had not registered any formal complaints, and at that time had only spoken of being invaded when the Chinese troops crossed the Upper Yangtse into what is now the TAR. Only in the late 1950s had there been nearly simultaneous protest in the eastern and western parts of Tibet, and its recurrence is of historic significance. ${ }^{(8)}$

The exceptional character of this east-west congruence in protest becomes clearer if we consider the demands made by the demonstrators. The march by Drepung monks on 10 March is said to have had three specific, non-political demands, such as the release of the five monks detained during the whitewashing of the former residence of the Dalai Lama in October 2007. The student protest at Northwest Nationalities University on 16 March carried a banner simply saying "Sharing happiness and suffering of Tibetans" (Bod mi"i skyid sdug mnyam myong). But such carefully calibrated statements were unusual. Especially after 14 March, protests appear to have had little organisation and rarely had single or specific demands or slogans, let alone tactically calculated ones. The majority of accounts that describe slogans or demands by protestors say that many calls related to the Dalai Lama - one hand-written banner said, "Invite His Holiness, strive for freedom" (Gong sa gdan zhu / rang $d$ bang rtsol) - and photographs of many protests show people brandishing pictures of the exile leader. This differs from protestors' slogans in the late 1980s, which were typically calls for independence or for the Chinese to leave Tibet. This probably reflects the extent to which the Dalai Lama in the last 20 years has changed the political focus of the

7. See for example, Fred Lane, "The Warrior Tribes of Kham," Asiaweek, 2 March 1994

8. The protests in Amdo also seem to be closely linked to places where there were major conflicts with the PLA, and alleged atrocities, during a campaign to repress dissent in 1957-58. Memoirs of these events have only recently begun to circulate in Tibet, either by word of mouth or in unofficial publications such as Nus Blo, Nags tshang zhi lu'i skyid sdug ("Boyhood Joys and Sorrows in the Nags Tshang family"), published privately by the author in Xining in 2007, and the series Rin bzang gi mu 'brel zin tho (Rinzang's Serialized Notes), including Rin bzang, Nga'i pha yul dang zhi ba'i bcing grol (My Homeland and Peaceful Liberation); Rin bzang, Nga'i pha yul dang gzab nyan (My Homeland and Careful Listening); and Blo bzang Don 'grub, Nga tsho'i mi rigs dang nga tsho'i bsam blo (Our Nationality and Our Thinking), all privately published probably in Amdo, 2008 
Tibet issue from independence to negotiations with China. It also shows the spread of ideas by overseas Tibetan-language broadcasters -Voice of America, Radio Free Asia, and Voice of Tibet, based in the United States and Norway and providing daily news reports of Tibet-related events in the outside world since at least 1990. But the biggest single reason for the Dalai Lama's increased status within Tibet has been China's policy of attacking him, a policy it began only in 1994 when it decided to make the Tibet issue primarily about his personal standing and so repeatedly attacked him in the press and required monks, nuns, and others to denounce him.

Reports about many incidents describe people shouting for Tibetan independence: importantly, the protests indicate that there is a widespread view among Tibetans that Tibet was a separate nation in the past. In at least 11 incidents protestors are known to have carried the Tibetan national flag, which is banned in China and is extremely dangerous to display (in December 1988, armed police in Lhasa shot two Tibetans dead at point blank range for carrying flags). Ten of the 2008 protests with flags took place in eastern Tibet mostly in areas of Amdo where that flag had never flown before, which had not been under Tibetan administration for centuries, and which before 1949 did not consider themselves to have been part of Tibet as a single polity. The use of the flags does not necessarily show (as some have claimed) that these protestors were demanding independence - the ubiquitous images of the Dalai Lama suggest that, like him, they think Tibet was independent in the past, but will nevertheless accept a negotiated solution, even if some wish for independence in the future. But they do suggest that the phenomenon of Tibetan nationalism and the idea of Tibet as a distinct nation are much more widespread than 20 years ago.

\section{Class and protest}

The 2008 events showed another major difference from earlier protests in post-Mao Tibet: the participants came from a wide range of social classes and vocations. Over 90 percent of political protests in Lhasa in the late 1980s were led by monks and nuns, and on the few occasions when laypeople were involved, they were usually from the new class of small traders - petty urban entrepreneurs who by the mid-1980s had just been given the chance to practice religion again and to operate small stalls in the street market around the central temple of the city. There were exceptions - seven political incidents were staged by farmers in villages in 1993, two stu-
Figure 2. Approximate distribution of lay, monastic, nun and student participants in the protests.

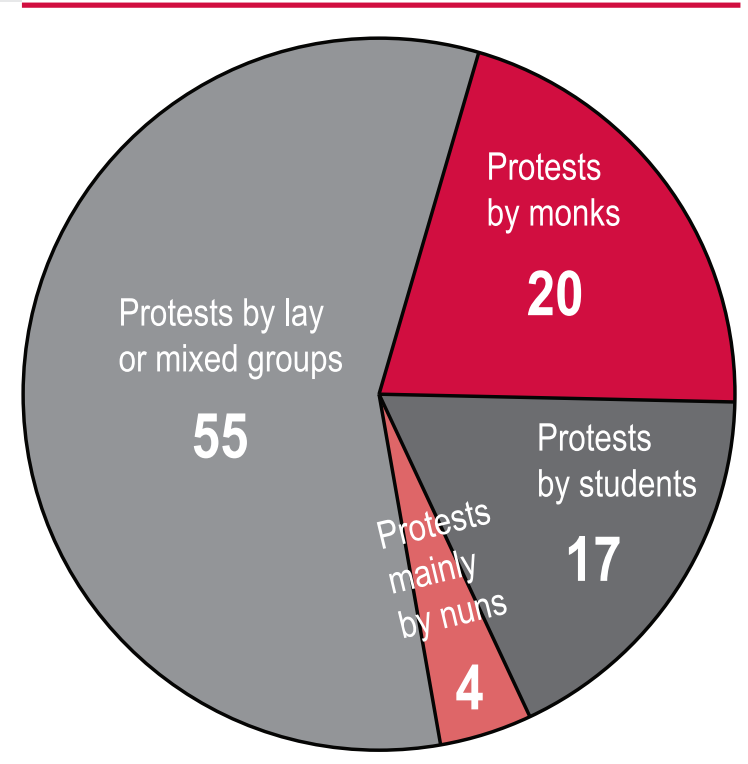

dents were famously arrested in 1988, and at least two symbolic, non-political protests were staged by students in Lhasa in 1989 and 1993 - but generally the range of participants was narrow. This phenomenon seems to have been partly responsible for Chinese policy-makers concluding that increasing the size and wealth of the Tibetan middle class (perhaps no more than 5-10 percent of the population) would buy loyalty and diminish unrest, a key theory underlining their decision after 1992 to increase the salaries and improve the living conditions of government employees in Tibet.

But even from the outline reports available so far, it is clear that far more classes of people were involved in the 2008 events. Thirty percent of the 95 reported incidents took place in villages or townships, and the proportion of rural incidents is likely to be much higher once more information becomes available. This must mean that a significant number of farmers took part, and in some cases nomads as well. The majority of the remaining incidents took place in small towns, often with populations of only around 5,000-10,000, which in some parts of the world would be considered rural communities. This means that in official terminology in China these events would be classed as peasant unrest or uprisings, and that they were staged by what is seen as the traditional power base of the Party - the social class that in theory gained most from direct rule and land distribution by China briefly in the 1950s and again after the disbanding of communes in the late 1970s. 
Figure 3. Comparison of type and degree of violence in 1987-1996 and March-April 2008 protests

\begin{tabular}{|c|c|c|}
\hline Violence in Protests in the 1980 s and 2008 & $1987-1996$ & March-April 2008 \\
\hline Total number of known political protests & circa 200 & At least 95 \\
\hline Number that were non-violent protests & c. 190 & c. 77 \\
\hline Number that were mainly lay protests & c. 7 & c. 50 \\
\hline $\begin{array}{c}\text { Number that were violent protests (as } \% \\
\text { of lay protests) }\end{array}$ & $3(43 \%)^{1}$ & $18(36 \%)^{2}$ \\
\hline $\begin{array}{l}\text { Attacks by protestors on civilian } \\
\text { bystanders (deaths) }\end{array}$ & 0 & 2 (18 deaths) ${ }^{3}$ \\
\hline $\begin{array}{l}\text { Attacks by protestors on state } \\
\text { property }\end{array}$ & $\begin{array}{l}\text { 3 } \\
\text { Included burning of police } \\
\text { vehicles and one included } \\
\text { burning of a police station }\end{array}$ & $\begin{array}{l}18 \\
\text { Included burning of vehicles, } \\
\text { police stations, government } \\
\text { offices and other buildings }\end{array}$ \\
\hline $\begin{array}{c}\text { Attacks by protestors on civilian } \\
\text { property }\end{array}$ & $\begin{array}{c}1 \\
\text { Included ransacking of a small } \\
\text { number of Chinese shops }{ }^{4}\end{array}$ & $\begin{array}{l}4 \\
\text { Included burning and ransacking } \\
\text { Chinese and Hui shops }{ }^{5}\end{array}$ \\
\hline $\begin{array}{l}\text { Attacks by protestors on security } \\
\text { personnel (deaths) }\end{array}$ & 3 protests ( 1 death) & 18 protests $(2 \text { deaths })^{6}$ \\
\hline $\begin{array}{l}\text { Deaths of protestors by security } \\
\text { forces }\end{array}$ & Estimates from 75 to 150 & Estimates from 30 to 219 \\
\hline
\end{tabular}

NOTE: Figures are estimates.

1. There may also have been minor violence in the three village protests near Lhasa in 1993, but details about these events are unclear.

2. Note that most violent incidents in 2008 occurred in or near Lhasa, in Sichuan or in Southern Gansu.

There were no deaths in Gansu protests.

3. The 18 deaths occurred during the Lhasa riot on 14 March, in which 132 buildings were burnt, and during the smaller riot in Dechen, Taktse county, 25 kilometres east of Lhasa, on 15 March, in which 23 buildings were burnt. 11 Chinese and 1 Tibetan died in shops that were set on fire by Tibetan rioters, who may have been unaware that the shops were occupied. The causes of the other 6 deaths are unclear. 4. This figure does not include damage during occasional ethnic riots (rather than political protests) by Tibetans against Hui Muslims.

5. The attacks on civilian property owned by ethnic Chinese or Hui migrants took place in Lhasa (14 March), Dechen (15 March), Machu (16 March) and Ngaba (16 March).

6. A policeman was killed in Lhasa or Dechen on 14/15 March and a policeman or soldier may have been killed in Drango (Ch. Luhuo), in Sichuan, on 24 March. There were many cases of serious injury.

Monks and nuns had staged the vast majority of protests in the previous wave, and in 1994, after a decisive meeting in Beijing called the Third National Forum on Work in Tibet, the state had begun a formal practice of targeting all "religious professionals" in Tibet pre-emptively as inherent political suspects. This was the rationale for the "patriotic education" drive that from May 1996 had sent teams of Party officials to spend three months in every monastery and nunnery in Tibet to demand written statements of loyalty to the state and denunciations of the Dalai Lama. The number of monks and nuns in Tibet had been frozen and quotas fixed at every institution. Semi-formal practices even emerged in Lhasa of banning monks and nuns from entering official premises, such as Tibet University, without advance permission. This profiling appears to have been intended to manage the chief sources of unrest. But only some 24 percent of the Spring 2008 protests involved monks or nuns alone; the other incidents were led by or included significant numbers of laypeople. Monks staged the incidents in the first three days from 10 March, but from that time on the bulk of the incidents were dominated by laypeople. This was a major departure from the previous pattern of protest.

In the earlier wave of unrest in Tibet, there had been little sign of involvement of the elite - officials, lamas, leading businessmen, or lay intellectuals - in protests. It is still unclear if members of these groups took part in any of the 
2008 protests, but 17 of the initially reported 95 incidents were staged by students, including at four of the five Nationality Universities (the special institutions designated by China for training the future elite from non-Chinese nationalities) that have Tibetan departments. And among those detained by the authorities in the sweep of suspects after the protests, we find the intellectual and singer Jamyang Kyi, the writers and bloggers Kunga Tsangyang (Kangnyi), Kunchok Tsephel, Lobsang Kirti, Thuksam, Dokru Tsultrim, Lodro Wangpo, Jamyang Phuntsok, and Go Sherab Gyatso; the film-maker Dhondup Wangchen; the singers Dabe, Drolma Kyi, Lhundrup, Tenzin, and Tashi Dondrup; the educators Palchen Kyab and Sonam; the lama Phurbu Tsering; and the AIDS/HIV educator Wangdu.

This suggests that the majority of 2008 incidents were largely rural, staged mostly by laypeople, with significant indications of elite involvement or support. These figures do not resolve questions about the proportion of the Tibetan population represented by the protestors - one Chinese estimate put the total number of participants at 30,000, about 0.5 percent of the Tibetan population. But it is clear that a very wide range of social groups and classes were represented in substantial ways in the unrest, and that there was a significant spread throughout Tibet across space and class of support for the Dalai Lama and of belief in Tibet as a separate nation in the past.

\section{Typology of protest}

The 2008 protests were distinctive for the relatively high amount of violence that took place. This violence became the chief feature of most representations of the events, especially in China, and was used as a determining factor in framing public responses, with different groups either overstating it or denying it. However, the violence in the 2008 protests should be compared with previous incidents of similar size and composition, since violence in Tibet usually occurs only in protests involving large numbers of laypeople or in rural incidents. In the 2008 protests, the number of participants in each protest was many times greater than in the previous wave, with probably at least 100 in each incident, if not many more, rather than 20 or so in the past. More than half the 2008 incidents involved laypeople, as opposed to about a tenth in the previous wave. It is normal for largescale, lay-dominated protests to lead to violence, firstly against the security forces, then against government property, and thirdly, if not checked by police, against migrant shops. ${ }^{(9)}$ A rough comparison shows that in 2008 the pro- portion of lay-dominated or rural incidents that became violent was about 36 percent, rather less than in the 1980s (c. 43 percent $\left.{ }^{(10)}\right)$. However, the number of deaths of civilian bystanders, mainly ethnic Chinese, caused by protestors in the Lhasa and Dechen riots of 14 and 15 March was far higher than in any previous incident.

There has been intense dispute over the number of Tibetan protestors killed by security forces during the 2008 protests or afterwards in custody, with figures ranging from eight to more than 200. Chinese authorities have admitted that troops opened fire at two protests in Sichuan in self-defence, but have said that no firearms were used by troops in Lhasa, which contradicts reports from eyewitnesses. The Chinese authorities have said at one time or another that eight $\mathrm{Ti}_{\mathrm{i}}$ betan protestors died in or shortly after the protests, but have either implied that their forces were not responsible or have later revised these reports. ${ }^{(I)}$

The distinctive features of the 2008 unrest become clearer if we examine the typology of protests. We can divide them into roughly six types:

Peaceful marches. These are pre-organised protests against specific restrictions or policies, in which a large number of people, typically monks or nuns, come together to hold a march or sit-down. This was what the Drepung and Sera monks did on 10 and 11 March, perhaps following a Burmese model of monastic protest. These events were mainly peaceful apart from scuffles when police tried to make arrests.

Flash-riots. A crowd forms spontaneously and very quickly because of a rumour or incident in the area, such as the protest of 21 February 2008 in Rebkong in Qinghai, and the Lhasa and Dechen incidents of 14-15 March. ${ }^{(12)}$ These

9. In both the protest in Lhasa on 5 March 1989 and the protest in Lhasa on 14 March 2008 , violence escalated from attacks on the security forces to widespread attacks on ethnic Chinese shops because few or no police were sent to control the situation for several hours. Bai Ma, chairman of the Qinghai Political Consultative Conference, said, "It is regrettable that authorities in Lhasa failed to take firm action to control the situation during the first few hours of the March 14 riots," and "heavy-handed and arbitrary tactics only create more animosity" (Shi Jiangtao, "Solution over Tibetans is 'more control,"' South China Morning Post, 26 April 2008).

10. Most of the 1987-96 protests involved very small groups of 10-20 people or fewer, almost always monks or nuns. There was no violence in those incidents.

11. The Chinese authorities said that three protestors died in Lhasa on 14 or 15 March (one had "jumped from a building when police came to arrest him" and two "were injured in the mayhem" (Materials on the March 14 Incident in Tibet (I), Foreign Languages Press, Beijing, 2008, p. 32); that four were shot dead in Ngaba on 16 March (the report was removed the next day - see note 4 above); and that a Tibetan called Tendar died while "awaiting trial for involvement in the protests" in Lhasa "from a disease" ("Police vioIence video a lie from Dalai Lama group," China Daily/Xinhua, 24 March 2009).

12. On the Rebkong incident see Charlene Makley, "Ballooning Unrest: Tibet, State Violence, and the Incredible Lightness of Knowledge," in Kate Merkel-Hess, Kenneth L. Pommeranz, and Jeffrey N. Wasserstrom (eds.), China in 2008: A Year of Great Significance, Lanham, Rowman \& Littlefield, 2009, pp. 44-56. 
typically are unfocused, tend to involve violence against property, and can last a long time if there is no effective action by security forces. They have no clear leadership, purpose, or slogans, and appear to tap into general discontent or prejudices, and so often have an ethnic dimension.

Protests supporting events elsewhere. These are focused protests in rural villages or small towns in response to news of an incident or anniversary elsewhere. These incidents tend to have broadly shared objectives and slogans. They may have improvised banners, and usually start with a march to a particular site, probably a government building or office. They may lead to violence against property or personnel, usually the property of the government. The March 2008 protests at Lutsa, Ditsa (Qinghai), and Labrang (Gansu) monasteries, and in Phenpo, Taktse, Medrogungkar (TAR), Ngaba (Sichuan), Chone, Tsoe, and Luchu (Gansu) were of this type, marking the anniversary of the 1959 Uprising or responding to news of the 14 March events in Lhasa.

Protests against a local incident. These are also focused protests in a rural village or small town but are in response to a specific incident that has just taken place in the same village or area, usually an abuse by local officials such as the arrest of monks at a local monastery. Again, the demands and targets are relatively specific. This happened in Drango, Tongkor, Nyatso (Sichuan), Medrogungkar (TAR), and other places from early April 2008 after patriotic education teams or search squads entered local monasteries in late March.

Sympathy protests. These are vigils or marches that express sympathy with those who suffered in previous protests, but express no demands of their own. The student protests at Nationality Universities were of this type. These were peaceful and were not broken up by police.

Solo protests. These involve single people or very small groups, often monks or nuns, staging symbolic protests in a town centre, often with a banner. Such gestures, effectively offering oneself up for arrest and beating on behalf of a community or cause, occurred increasingly in Sichuan from late March 2008. They are often carried out by women. These are always peaceful (though one case in Ngaba on $27 \mathrm{Feb}$ ruary 2009 involved self-immolation) but have led to immediate arrest, often very brutally, and in some cases protestors have reportedly been fired upon.

The flash-riots of type 2 are not new to Tibet. The three riots in Lhasa in 1987, 1988, and 1989 were against the Chinese government and were not driven by ethnic animosity, and the smaller riots in Lhasa in 1995, Chentsa (Ch. Jianza) in Qinghai in 2002, and Golok (Ch. Guoluo) in
Figure 4. March-April 2008 protests death estimates

\begin{tabular}{|c|c|c|c|c|}
\hline \multirow{2}{*}{\multicolumn{2}{|c|}{ Deaths in 2008 protests }} & \multicolumn{3}{|c|}{ estimates } \\
\hline & & $\begin{array}{c}\text { PRC } \\
\text { officials }\end{array}$ & $\begin{array}{l}\text { International } \\
\text { Campaign } \\
\text { for Tibet }\end{array}$ & $\begin{array}{l}\text { Tibetan } \\
\text { Exile } \\
\text { Government }\end{array}$ \\
\hline Tibetan protestors & $\begin{array}{l}\text { killed by } \\
\text { security } \\
\text { forces }\end{array}$ & 8 & $140^{1}$ & 219 \\
\hline Bystanders/civilians & $\begin{array}{l}\text { killed by } \\
\text { protestors }\end{array}$ & 18 & 18 & [not given] \\
\hline Security personnel & $\begin{array}{l}\text { killed by } \\
\text { protestors }\end{array}$ & 1 & 2 & 1 \\
\hline \multicolumn{5}{|c|}{$\begin{array}{l}\text { 1. The most detailed accounts from exiles named at least eight } \\
\text { Tibetans shot dead in Ngaba (Ch. Aba) in Sichuan on } 16 \text { March; } \\
\text { ten in Tongkor near Kardze (Ch. Ganzi) in Sichuan on } 3 \text { April; four } \\
\text { in Kardze (Ch. Ganzi) in Sichuan on } 18 \text { March; three in Dabpa (Ch. } \\
\text { Daocheng) in Sichuan on } 16 \text { March; one in Phenpo near Lhasa on } \\
15 \text { March and another in Drango (Ch. Luhuo) in Sichuan } \\
\text { on } 24 \text { March. }\end{array}$} \\
\hline
\end{tabular}

Qinghai in July 2007 were explicitly ethnic, in those cases against Hui Muslims. Dispersed violence and ethnic attacks are usual in incidents of this type, wherever in the world they occur. The type 6 or solo incidents are similar to the majority of protests in the 1980s phase. The protests of type 4 are usually rural and often violent, and have seen a very major increase in Tibet in the last year, but are similar in principle to the numerous protests that occur across China. Considered alone, they might be less troubling to Chinese leaders because they do not imply coordination or organisation and in theory can be averted by local policy changes or by replacing or disciplining local officials.

The other three types of protest, however, are new: coordinated Burmese-style peaceful marches or sit-downs by large numbers of monks; village protests in support of events hundreds of miles away or years earlier; and explicit gestures of sympathy by elite students. The majority of events in March of 2008 were village protests of type 3, mainly rural responses to the events in Lhasa on 14 March. Most protests since the end of March 2008 have been of types 5 and 6 reactions to responses by local officials to the March events (particularly the re-sending of patriotic education teams or paramilitary troops into local monasteries). These forms of resistance involve major sectors of the population not previously engaged in protest, and they imply effective knowledge of history, rapid spread of news concerning Tibet-wide events, and shared beliefs. In particular, the village protests 
of type 3 represent the largest Tibetan population group 85 percent of Tibetans in the TAR live in the countryside. With no tradition in villages for coordinated, peaceful protest, a degree of violence in village incidents is likely despite repeated calls for non-violence by the Dalai Lama. From this, we can identify the striking features of the 2008 protests: the flash-riots were more severe in the amount of violence involved, but this was related to the fact that the new protests involved a far greater number of participants than before in each incident; a far greater number of laypeople among those participants; a much greater number of rural people, students, and organised monks; and much faster sharing of news and perceptions of shared interest across the plateau. If we combine this with data on the geographic and social spread of the incidents, we can see that the 2008 protests indicate the politicisation and radicalisation of previously dormant classes of lay Tibetans, particularly the farmers and nomads of eastern Tibet, supported by students from the new, middle-class urban elite and by increasingly sophisticated monastic groups.

\section{Disentangling representation from cause}

Why, then, has much of the discussion focused on the question of violence? For political leaders, the primary question is or should be why this major spread of political activity and consciousness has taken place among Tibetans. Narratives of violence help both sides avoid other questions and consolidate their positions. From a Tibetan point of view, violence is by the Chinese state and exposes it as repressive, while at the same time it justifies violence by protestors. From a Chinese perspective, violence is by Tibetan nationalists and explains why strong, military measures were necessary, while fuelling (for no clear reason) the claim that unrest was externally instigated. In fact, violence is emotively potent as an image but may explain little about the causes of protest, since it can occur for many reasons besides those that led to the unrest. To explain the breadth of unrest one either has to find evidence of coordinated instigation or to study systemic factors such as government policies and social conditions. In the Tibet case, however, the study of these questions has been largely replaced by disputes in the media over the meaning and nature of the unrest, so that arguments about causes are indistinguishable from the way they are presented. In this case, representation, and even public manipulation of data, is used by all sides as a way to avoid unwanted answers to questions about causes. This may explain why there has been little serious discussion in the Chinese media about the causes of unrest. ${ }^{(13)}$

There were reasonable grounds for analysts to consider whether the 2008 events might have been coordinated. They involved similar political activity taking place at the same time across great distances, to a degree that had not happened before. On 10 March, there were five similar events - peaceful protests by large numbers of monks - at locations (Lhasa in the TAR, and Ditsa and Lutsa in Qinghai) about 1,000 kilometres apart. This coincided with an initiative by five exile groups in India to launch what they called a "People's Uprising," which involved a "Peace March" of 100 exile Tibetans starting from New Delhi on that day with the supposed objective of crossing the border into Tibet. The exiles' declared plan was to stimulate activities that would upset the Olympic Games, due to open in Beijing the following August and widely regarded as a test of China's acceptance into the international community. The second round of protests, those that began with the riot in Lhasa on 14 March, also showed near-simultaneous activity across a wide area. The 90 or so incidents that took place over the following month were not spread out evenly: at least 64, and probably many more, took place within 72 hours of the Lhasa riot. This, too, could be considered a possible indication of some kind of co-ordination.

Within hours of the 14 March riot, the Chinese media said that the Dalai Lama had planned the events, including the violence. Sections of the Chinese media implied that the Dalai Lama had personally coordinated the protests and the premeditated acts of violence. At higher levels of the leadership the blame was placed more diplomatically on "the Dalai clique." As China's Premier put it on 18 March, "This incident was organised, premeditated, masterminded and incited by the Dalai clique." ${ }^{(14)}$ Evidence in support of this claim was published by the official Chinese press on 31 March. ${ }^{(15)}$

However, this evidence was largely rejected by the international media and politicians as insubstantial: it was either unverifiable or appeared to show the normal rhetoric of campaign groups in exile that was directed towards the mobilisation of other exiles rather than those inside Tibet. Much of it differed little from many years of similar sloganeering.

13. The social and economic causes were raised in detail in China for the first known time in a study by a Chinese NGO, Gongmeng or Open Constitution Institute (see Holzman's paper in this issue).

14. "China blames Dalai Lama for riots," BBC World Service, 18 March 2008 at http://news.bbc.co.uk /2/hi/asia-pacific/7302021.stm.

15. "Dalai clique's masterminding of Lhasa violence exposed," China Daily, 30 March 2008. 
Figure 5. Chart showing the number of protests day by day in each province from 10 March to 5 April 2008

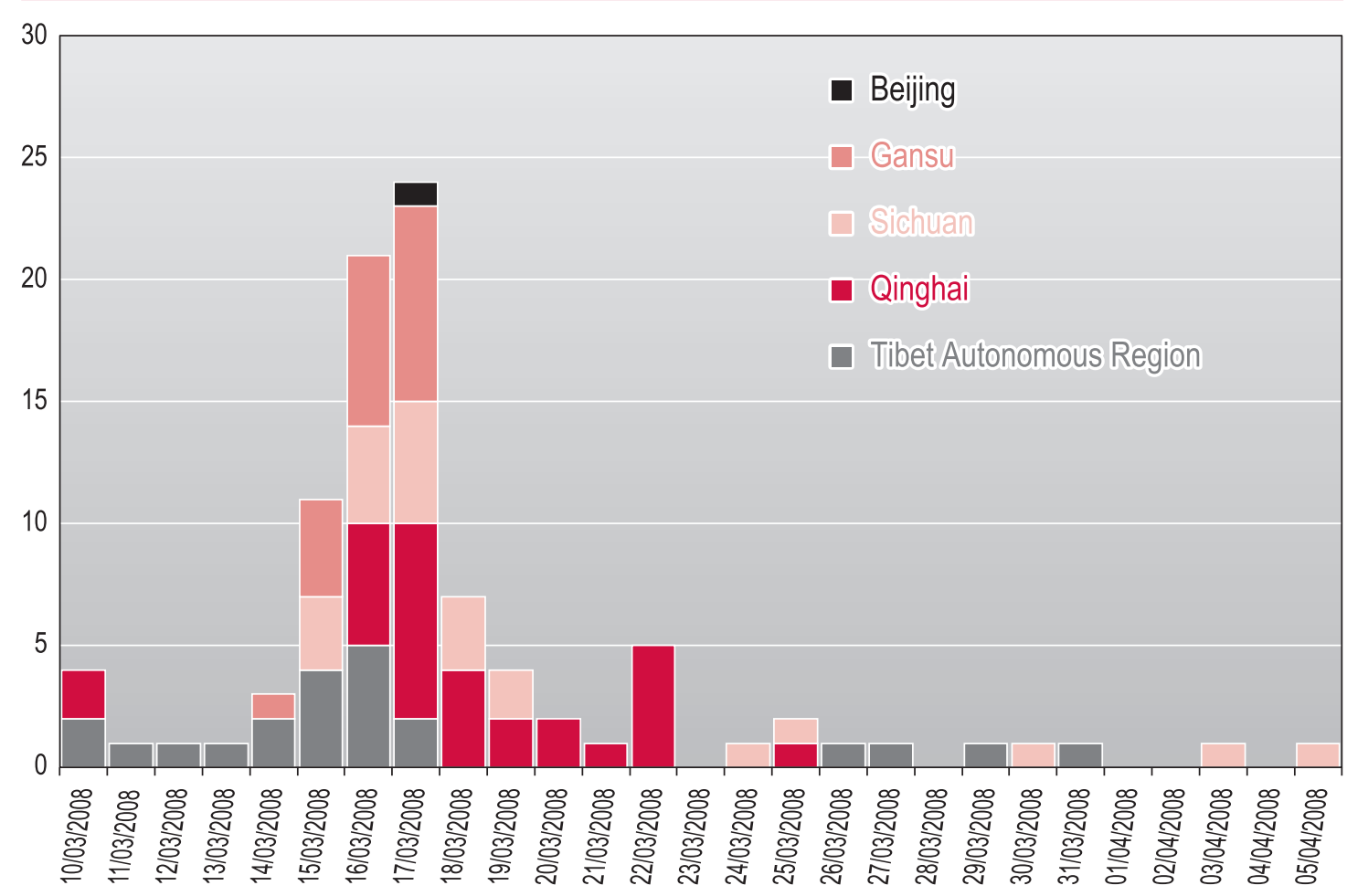

All data is provisional, based on media and web reportd and includes unconfirmed data.

Scholars such as Tsering Shakya pointed out that exile activists have shown negligible ability to organise anything inside Tibet or even to make significant contacts there, implying that much of their rhetoric, too, may be overstated. ${ }^{(16)}$ Underground organisations did operate in Tibet until most were crushed by improved State Security operations in 1993, and any activities since then seem to have been limited to circulating information. Despite frequent pre-trial media rhetoric about foreign instigation, in the last 20 years the Chinese security services are not known to have produced a court case demonstrating any substantive link of exiles to unrest in Tibet. ${ }^{(17)}$ In the last five years an increasing number of young Tibetans educated illicitly in exile schools have moved back to Lhasa and other Tibetan areas, often with ardently nationalist convictions, but their activities and identities are so conspicuous to everyone that the security services would certainly have had easy access to any efforts they might have contemplated. As before, the state has generally accused these returnees only of circulating information, not of planning protests or unrest.
The chief difficulty with claims of instigation is that easier explanations abound. All the information necessary for events to take place at roughly a similar time was circulating worldwide in the international media, and these media outlets had been available for several years to most Tibetans through short-wave radio and satellite broadcasts from abroad. These broadcasts reach rural areas of Tibet more easily than urban areas, around which jamming stations are clustered. There was extensive publicity outside China and on these radio stations about exile plans to disrupt the preparations for the Olympics and to hold a march in India on 10 March, the anniversary of the 1959 uprising that had led to the Dalai Lama's exile. It was implicit in these reports that China would be less likely to use lethal force on protestors

16. "Tibetan exile groups in India do get [U.S.] funding, but that does not translate into an ability to mobilize in the PRC. There is a huge social and cultural gap between Tibetans in India and those in the TAR, illustrated even by their taste in music" (Tsering Shakya, "Interview: Tibetan Questions," New Left Review 51, May-June 2008, p. 22).

17. As far as I know, the only documented case of exiles creating an incident inside Tibet was the attempt to set off a small explosion at the 1985 celebrations of the 20th Anniversary of the Tibet Autonomous Region. The device failed to go off. 
in the run-up to the Olympics, and it was well known that the Dalai Lama was involved in advanced stages of talks with the Chinese authorities, which protestors may have hoped to influence. Once a protest happened in Lhasa, news would have spread quickly across the Tibetan community, since cellphone use among Tibetans is prolific, and many eastern Tibetans live in Lhasa as monks, traders, or state employees. Social networks in eastern Tibet would in any case have been particularly engaged in events in Lhasa on 10 March because the second protest in Lhasa that day was staged by 14 monks from Amdo, and news of their detention and beating would have spread quickly to their relatives and fellow-monks in eastern areas. Some Chinese cyber-activists have said that news of the Lhasa protests on 14 March was spread by foreign radio stations, and Western media reported that the Chinese authorities did not allow footage of the riot to be shown in mainland China until two days after it happened (supposedly because of pressure from Chinese nationalists who had seen images of the violence on the web $\left.{ }^{(18)}\right)$, but some Tibetans in Amdo have said that images of violence in the Lhasa riot were shown on television in their areas on 14 March. ${ }^{(19)}$

There were events that did show some planning and coordination, such as the largely peaceful marches by the Drepung and Sera monks on 10 and 11 March with their careful slogans and restrained tactics, though this degree of self-regulation is to be expected from members of a single, closely connected community. But these were not the protests featured by the official media in China. Instead the Chinese media and cyber-community focused on incidents that showed violence, chiefly the one in Lhasa on 14 March. To put it another way, they discussed riots and ignored demonstrations. Like most riots, the Tibetan ones were intrinsically chaotic and did not show obvious signs of being organised, with no prepared banners or focused objectives, and no obvious evidence of leadership or management. Press accounts and officials in China focused on other, more subtle signs that might indicate the presence of agents provocateurs in the riots. A Hong Kong paper quoted a bystander in Lhasa (apparently a Chinese person, but this information was withheld) as saying that special knowledge must have been necessary to know how to torch a car; some bloggers said that special equipment must have been needed in order to burn down shops quickly; other commentators reported that $\mathrm{Ti}$ betan protestors had carried backpacks full of stones. ${ }^{(20)}$ The Ministry for Public Security announced that some participants had confessed during interrogation to being paid by a named former monk-convict to set fire to shops and attack
non-Tibetans. ${ }^{(2)}$ Television and newspapers showed photographs of guns and other firearms police had found in a number of monasteries across the Tibetan plateau. ${ }^{(22)} \mathrm{A}$ more elaborate theory by an independent writer in the U.S. tried to prove that the protests were part of a secret plot planned and funded by the Washington, D.C.-based National Endowment for Democracy. The writer is associated with publications arguing that the 2001 destruction of the World Trade Centre was a conspiracy by the U.S. intelligence services, and he later withdrew the article under threat of legal action, but by then it had been given top billing on China's main television news program and had been reproduced in many papers in China, Singapore, and Hong Kong. ${ }^{(23)}$

Among Tibetan exiles and their supporters, a similar array of conspiracies was developed, which alleged that the riots had been provoked by Chinese agents disguised as Tibetans. These arguments had little strategic benefit for their proponents except seemingly to allay embarrassment at the discovery that Tibetans were capable of violence. A conspiracytheorist based in Canada published an article claiming that British intelligence had satellite images showing that soldiers had been seen changing into monks' robes; an unnamed Thai tourist was said to have told an exile that she had recognised a Tibetan policeman among the rioters; the Falun Gong newspaper Epoch Times published articles citing as fact the unproven claims of Chinese dissident Tang Daxian in 1989 that agents provocateurs had been used at that time by the Chinese authorities to stir up riots in Lhasa; and $\mathrm{Ti}$ -

18. See "State TV switches to non-stop footage of Chinese under attack," The Guardian, 18 March 2008, at http://www.guardian.co.uk/world/2008/mar/18/tibet.china1.

19. Mgar mi, "Zungs khrag dang tshe srog gi gtug bsher" "'The Case for Life-blood and Lifeforce"), in Shar dung ri (The Eastern Conch Mountain), Vol. 21 (2008), p. 117. Published in English translation in A Great Mountain, ICT, pp. 99-102.

20. People in Lhasa knew immediately how to torch cars in the 1987 protest, since it is very easy (one just lights a rag and inserts it in the petrol tank); the shops were torched quickly because the arsonists only had to turn on and light the gas cylinders used in each one for cooking or heating; stones were available everywhere in the city because of construction sites.

21. See "The truth about the severe criminal violence of attacks, destruction, robbery and burning events on 14 March, Lhasa, Tibet" (in Chinese), Ministry of Public Security of the People's Republic of China, 22 March 2008. Accessed at http://app.mps.gov.cn: 9080/cenweb/brjlCenweb/jsp/common/article.jsp?infoid =ABC00000000000043861.

22. The description of these as weapon hoards were dismissed by Tibetans, who pointed out that disused weapons are normally deposited in protector-chapels in monasteries as part of certain rituals (See Bud Dha, Phyir rtog dang bsam gzhig (Hindsight and Reflection), Shar dung ri (The Eastern Conch Mountain), Vol. 21 (2008), pp. 95-6; for translation, see $A$ Great Mountain, ICT, p. 84). There have been no claims by Chinese or any media or officials since at least October 1987 that Tibetans have used firearms in any protest.

23. F. William Engdahl, "Risky Geopolitical Game: Washington Plays 'Tibet Roulette' with China," Global Research, 10 April 2008. See Ji Gong (Ching Cheong), "Tibetan Riots: The Crimson Revolution's True Colour," 19 June 2008 at http://english.chinatibetnews.com/ voices/2008-06/19/content_107704.htm, originally published as Ching Cheong, "The crimson revolution's true colours," Straits Times, 22 April 2008. 
Soldiers claimed by exile leaders to be PLA provocateurs dressing up as monks during the 14 March riot in Lhasa. In fact the photograph shows soldiers working as extras on a Michele Yeo film, The Touch, in Lhasa in 2001. ㅇ TCHRD

betan bloggers argued that Chinese press photographs showing Tibetan rioters holding unusually long knives had been faked. A photograph of Chinese soldiers holding monastic robes was circulated on the internet as proof that the soldiers had been dressed as monks (though there was little involvement of monks in the rioting in Lhasa). The photograph was in fact a shot of soldiers dressing up to perform as monks during location shooting for a Hong Kong film starring Michelle Yeo, The Touch, in Lhasa in 2001. The claim that this photograph proved that Lhasa rioters were Chinese was repeated by the exile Tibetan Prime Minister and even referred to by the Dalai Lama, according to some reports. The Chinese media ridiculed the claims by publishing an interview with a soldier who had led the soldiers shown in the photograph seven years earlier. ${ }^{(24)}$

These conflicting perceptions, each seeing the other involved in premeditated deceit, were embedded within complex webs of representation that had much more significance and purchase than the conspiracy theories themselves. Each was founded in a basic perception about the nature and cause of the events that had taken place, each used a different term to describe those events, different images to personalise their core meaning, and different but equally logical steps to lead people to starkly opposed political conclusions.

Two polar perceptions can be identified in this case, together with the secondary opinions that formed around the cluster of associated ideas. The "A-type" argument, most often associated with "the Chinese" (though it was of course held by many who were not Chinese, and not held by some who were), takes as its basic premise that the events of March 2008 were riots (in socialist times, they would have been termed rebellions), their principal characteristic being randomised violence. The emotional impact of this view was secured and reinforced by repeated showings in the media of a limited stock of video footage and photographs of ordinary Chinese being pursued and beaten by Tibetans with knives, and by images of Tibetan youths breaking into shops. A number of photographs and articles highlighted the involvement of monks in unrest. The images and arguments that fuel this perception were heavily featured in presentations on the internet by ethnic Chinese activists, both domestic and diasporic, such as a YouTube video called "Tibet Was, Is and Always Will Be Part of China" and the website anti-cnn.com, ${ }^{(25)}$ but the circulation of the same images and anti-exile accusations was heavily promoted by the government too, such as in touring photographic exhibitions in China. ${ }^{(26)}$

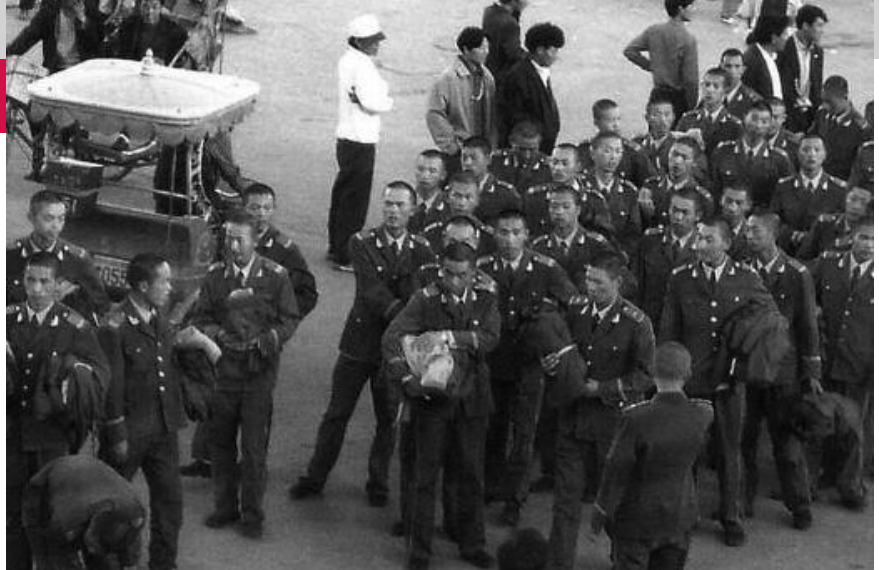

From the A-type perspective, the random, incoherent quality of the violence appears as ethnic hatred and is directed into an argument that explains, as if it were self-evident, that the hatred is a result of Tibetan jealousy of Chinese and Hui economic success. The jealousy is seen as manipulated by the exile leadership or its Western allies, who use economic difference to increase Tibetan nationalism and unsettle China. This leads to three principal conclusions: despite their claims, the exile Tibetan leadership is secretly pursuing independence while pretending to seek only autonomy; the Dalai Lama is a hypocrite and liar trying to damage China and trick the world; and Tibetans are planning terrorist operations or are innately prone to violence. These conclusions are implicit throughout official Chinese press responses to the unrest, as well as in public writings on the internet. The first two were directly stated almost verbatim in the official, public rejection of the exile Tibetan proposal on autonomy on 10 November 2008 by China's top Tibet policy-makers. The "B-type view," associated with Tibetan exiles and their supporters, uses the term "protests" to describe the unrest of Spring 2008; among more ardent nationalists, the term "uprising" is used. The word "riot" is avoided even for the 14 March incident. The protests are described as largely peaceful. The key images that underscored this perception are those of the protestors shot dead in Ngaba on 16 March, and those of young women and monks who had been killed in the protests or who have since disappeared. The unrest is explained as uncontrollable frustration with China's continuing presence as an occupying force in Tibet or, depending on one's view, as responses to its on-going policies. Analogies of the unrest with a boiling pot or pressure cooker, or references to long simmering tensions, are often found. In this argument, the conclusion is sometimes drawn that China can be embarrassed by these revelations and loss of stature and pressurised to change its policies. The secondary

24. Gordon Thomas, "Beijing orchestrating Tibet riots: Brit spies confirm Dalai Lama's report of staged violence," Canada Free Press, 21 March 2008; "China disguising soldiers as monks to incite riots: Dalai Lama" IANS, 20 March 2008 at http://www.thaindian.com/ newsportal/uncategorized/china-disguising-soldiers-as-monks-to-incite-riots-dalailama_10032556.html; "China rejects rumor of soldiers disguising as rioting monks," Xinhua, 31 March 2008 at http://news.xinhuanet.com/english/2008-03/31/content 7893926.htm.

25. For the video, see http://www.youtube.com/watch?v=7KNzRXNmSdM.

26. Photographic exhibitions showing large-format photographs of monks in the protests toured China during the summer of 2008 (see "Truth of Lhasa 3.14 riots photo exhibition held in Guangxi," China Tibet Information Center, 22 June 2008 at http://eng.tibet.cn/news/today/200806/t20080622_408489.htm). 
Figure 7. The "A-type" representation cluster: interpretations of the March protests, with secondary opinions and conspiracy theories

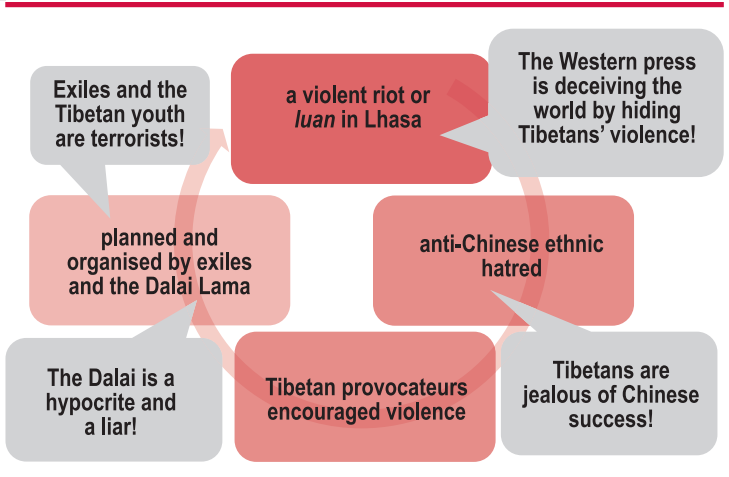

and more emotive concepts in this cluster stress the instances of brutality by security forces, argue that Tibetans were undeserving victims, and, as we have seen, sometimes claim that violence during the protests was instigated by Chinese agents disguised as Tibetans. A general conclusion is drawn that Tibetans are more or less united in their opposition to Chinese rule, that the Chinese authorities lack moral or practical legitimacy, and that the Tibetans are deserving for humanistic reasons such as sympathy with their plight. Among a more extreme subgroup of Tibetan radicals and their supporters a more particular conclusion is drawn, namely that the unrest proves that Tibetans inside Tibet seek the restoration of Tibetan independence, and that the efforts at negotiation by the Dalai Lama and the exile leadership are politically, even morally, incorrect.

\section{Framework views and their consequences: Nation versus state}

Some elements of these two positions seem similar. Both seek evidence of conspiracies, both focus on violence, and both see a sharp increase in nationalism among Tibetans. But the differences become clearer if we attempt to identify the framing concept that is basic to each view. It seems to me that at the core of the thinking of both groups is the visceral conviction that the nation-state is the only organising concept of politics and history, indeed of life in all its public forms, much as Duara has suggested. ${ }^{(27)}$ But the groups are divided by radically different perceptions as to what a nation-state is. The A-type group sees it and thus all political life in terms of a state, in the sense of a
Figure 8. "B-type" interpretations of the March protests, with derivative opinions and theories

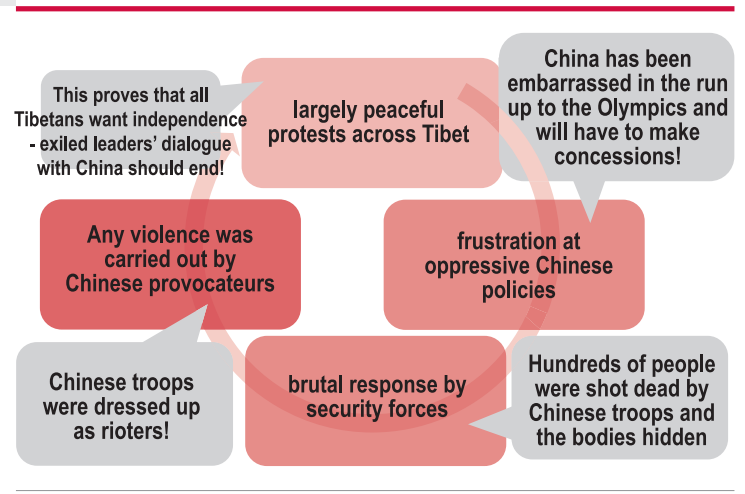

largely administrative entity that is entitled to demand certain forms of compliance from its citizens as long as it provides them with certain goods, and which is entitled to use lethal force where necessary to protect the welfare of the statistical majority. In this view, conflict between groups within a community is inevitable because of different interests, and only a state with such powers can contain and balance conflicting interests. The key notions in the statist view are, in the current Chinese context, conveyed by terms such as "stability" and "harmony," suggesting a necessary and beneficial set of limitations on citizens in order to maintain a larger, common equilibrium. Recently, proponents for this view have used the concept of Confucianism as a culturalist explanation for this model, or have pointed to the family as the fundamental unit of social order in this approach.

This view is similar to realist in general. The statist anywhere tends to see the world in mechanistic rather than humanistic terms, as a necessary contrivance where conflicting interests must be balanced. The nature and definition of the state, like its borders, are indisputable, and economic relations seem self-evidently the most logical way to view and organise differences and interests. Arguments that frame Tibetans or other players as primarily economic agents driven by a need for more resources, wealth, or income, are usually operating within and reinforcing the statist view, often without realising it. The notions of ethnicity, ethnic groups, and

27. "The modern territorial nation and linear history have an intimate relationship. Indeed, one might say that they co-produce each other as the principal mode of belonging in the twentieth century. Individuals learn to identify with nation-states that have supposedly evolved over a long history to reach the self-conscious unity of the two and are thus poised to acquire mastery over the future" (Prasenjit Duara, "The Regime of Authenticity: Timelessness, Gender and National History in Modern China," History and Theory, Vol. 37, Issue 3, October 1998, pp. 287-308. 
ethnic conflict similarly belong to this framework, implying an interests-based notion of groups whose competing drives and needs can only be moderated and contained by a powerful organ like the state. ${ }^{(28)}$

The B-type view appears to takes as its basic framework the idea of the nation, which is seen as a largely indistinct heritage of intangible goods that belongs to one group of people and no other, and that can only be sustained and fully comprehended by members of that group. It sees a common purpose, which is never a purely economic one, for that group, a "spiritual principle" as Renan called it, ${ }^{(29)}$ and it sees interference with that principle by outsiders as a primary act of injustice or inhumanity. In many, though not all cases, it is fused with an idea of territory as well, though it can be based just as easily on language, customs, or religion. It is driven by a notion of survival and a fear of extinction on behalf of something that it celebrates as being by its nature hard to define or identify. If it has to refer to the subsidiary elements of the nation, the important ones are culture, history, and nature, not economics. Its primary concerns are not with interests or duties but with rights and freedoms, and it reaches for system-level change as a solution. It appears often to envisage this collective thing it calls a nation as if it were an individual, as an organic entity that has invisible needs and anxieties like a person, and that is vulnerable and prone to injury and weakness, needing to be nurtured, protected and sustained.

Reducing the two positions to their primary differences and their founding metaphors elucidates the gulf of incomprehensibility between them. In theory it also points to ways in which common interests can be identified. As the cognitive linguist George Lakoff has written of the rift that divides political factions in the contemporary United States:

\section{The Enlightenment theory of reason doesn't describe how people actually work. People think primarily in terms of cultural narratives, stereotypes, frames, and metaphors. That is real reason. ...Realities matter. To communicate them, you have to make use of real rea- son. ${ }^{(30)}$}

The B-type or nation-based perspective outlined here has already had important consequences, such as polarisation within the exile Tibetan community between those who see in the unrest of 2008 a mandate for the leadership to pressurise China to negotiate, and those who see it as a vindication of the pro-independence faction and a rejection of the Dalai Lama's concessional approach. For both groups, the narratives of victimhood imply that the two communities, those inside Tibet and the exiles outside, have a common purpose, but provide none of the detail that would make that story intelligible or useful. They demonstrate that many people inside Tibet disapprove strongly of Chinese rule, without indicating precisely which aspects of that rule they condemn or which solutions they foresee as viable.

The narratives generated by the statist or A-type view have more serious effects, since in the Chinese case they have been absorbed and recirculated, if not instigated, by a powerful government, as well as by Chinese cyber-activists. On the one hand, this has seeded and nurtured a new wave of popular nationalism among many Chinese people, both inside and outside China, in response to the Tibet unrest, so that they feel empowered and entitled to challenge in their own terms Western or hostile representations of China and its policies. The new fenqing have achieved singular successes in contesting foreign representations of Tibet and appear to have influenced policy-making and public opinion at least within China and its diaspora by providing coherent counterarguments or by stimulating threats of popular actions, such as mass boycotts against French companies. This approach appears to have been incorporated by Beijing in its international relations, since it has significantly stepped up its threats against Western leaders who plan to meet the Dalai Lama, even cancelling an EU-China summit in December 2008 because of a planned meeting between the French President and the Tibetan leader. For the new nationalists, their success at cyber-politics comes at the cost of a larger loss in humanistic vision: being able to persuade hundreds of thousands of people that the Dalai Lama is a fawning hypocrite demonstrates discursive power but questionable judgement, since in the mid- to long-term nations stand to benefit from moral heroes and advocates of reconciliation, even flawed ones, rather than from destroying them.

For the Chinese government, the narrative of conspiracy has had more serious consequences. Branding the Tibetan un-

28. The "ethnicity" approach has grown in importance in China since the 1990s, as seen by the decision by the state in about 1995 to change all official translations of the word minzu from "nationality" to "ethnic" or "ethnicity." The 2008 decision to change the name of the Central University of Nationalities to "the Central Minzu University" also suggests a decision among Chinese officials to avoid using the English word "nationality" to describe a group within China, since that word often describes a people that have a separate state.

29. "A nation is a soul or spiritual principle.... A nation is therefore a huge solidarity, constituted by the feeling of sacrifices that have been made, and which will continue to be made." Ernest Renan (1823-92) "What is a Nation?", lecture to the Sorbonne, 11 March 1882, translation by Martin Thom from Homi Bhabha, ed., Nation and Narration, London: Routledge, 1990, pp. 8-22

30. “Don't Think of a Maverick! Could the Obama Campaign Be Improved?", George Lakoff BuzzFlash.org, 11 September 2008 at http://blog.buzzflash.com/contributors/1743. 
rest as foreign instigation allowed the relevant officials in the area to stay in power and escape censure. It also created domestic support for the state's decision to crack down on $\mathrm{Ti}^{-}$ betans. But it also destroyed, or at least suspended for the time being, two key mechanisms of the Communist Party that have kept it in power - its ability to respond flexibly to grassroots needs in time to avert major challenges, and its foundational claim to give equal treatment to its citizens, or at least to certain recognised groups of citizens such as the 55 minorities. Publicly accusing the Dalai Lama of personally planning riots in Tibet would have cost the CCP little in the long run if at the same time it had carried out grassroots inspections in the Tibetan communities that staged riots and protests in 2008 and identified which policies had fuelled the unrest and needed changing. Although at least five inspection teams were sent to Tibet, it is said among Tibetan officials that none of the participants dared to write in their reports that the causes of unrest were failed policy rather than instigation by the Dalai Lama or his colleagues. ${ }^{(31)} \mathrm{A}$ year after the unrest began, despite public hints from high ranking Tibetan leaders such as A Thrin (Ch. Acheng) and Jampa Phuntsog (Ch. Qiangba Puncog) that identifying failed policies is more important than conspiracies, ${ }^{(32)}$ there is no sign of any attention by Beijing to local concerns or any reconsideration of its Tibet policies.

Meanwhile the narrative within China of foreign threat has led to a new perception of Tibetans as hidden terrorists or as inherently violent. When a "dark-skinned man" was described by a witness as having shot a soldier in Chongqing on 19 March 2009, even the China Daily, China's foremost English-language organ, announced that this meant that the assassin was probably Tibetan. ${ }^{(33)}$ For many urban Tibetans, the most important indicator of current Chinese policies after March 2008 was that they could not get admission to most hotels when they travelled to the mainland, and that they were singled out for special searches at Chinese airports because they were Tibetans. These new practices, still in force at the time of writing, are more significant for many Tibetans than the extensive and long-lasting restrictions on religion, speech, or writing, because they invalidate the Party's claim to treat all nationalities equally - a claim that, contrary to many foreign expectations, is quite widely seen in Tibet as having been largely kept until now in terms of formal laws and public policy statements. It is not hard for anyone to understand why an authoritarian government bans Tibetans from worshipping the Dalai Lama, since in Tibet he is more popular than state leaders, or why it refuses to allow street protests to criticise their policies or historians to write freely about the status of Tibet in the past, since these could undermine their legitimacy. But however much a realist one is, it is hard to find logic to explain why the government in Beijing has not overturned a policy that prevents Tibetans (and Uyghurs, and sometimes Mongolians) from booking rooms in hotels in Shanghai or Xi'an because of their ethnicity.

The short-term benefits for China of representing the 2008 unrest as a foreign plot have thus produced a long-term problem, which is that the state is now increasingly likely to be perceived by Tibetans as acting according to an agenda of Chinese superiority and ethnic destiny. The difficulties and tensions that modern China has asked Tibetans to see as a problem of uneven development within a single nation-state are now more likely to be seen by Tibetans in Tibet as resembling colonial rule or endemic state discrimination, since the dominant rhetoric in China and its cyber-activists exhibit the hallmarks of that approach.

\section{Conclusion}

In conflicts over representation, the represented disappear, their voices muffled by the disputes among those who seek to represent them. The distinctive feature of the Tibetan case is that this struggle over representation is carried out by outsiders, with little influence from the participants themselves, a double stripping of autonomy. The muting process is compounded by years of Chinese policy in Tibet, which has since 1959 been designed to silence and isolate internal expression and debate. Thus the images of violence selected and circulated by outsiders become the most influential element of the recent protests and shape responses to them, and the complex and varied thinking of protagonists inside Tibet becomes increasingly difficult to discover.

31. Interview with a middle-ranking Tibetan official, 2009. Name and date withheld.

32. Jampa Phuntsog, Governor of the TAR, said: "There were all kinds of people [in the riot], some of whom weren't satisfied with our policies, or had opinions about them, of because our government work hadn't been fully completed. Not everyone was a splittist” (Lucy Hornby, "Tibet chief rules out 'big problems' during anniversaries," Reuters, 5 March 2009). A Thrin, a former governor of Karze (Ch. Ganzi) prefecture, said "The government should have more trust in its people, particularly the Tibetan lamas, most of whom are not troublemakers" (Shi Jiangtao, "Is Beijing playing a no-win game?" South China Morning Post, 12 March 2009), and a monk "is a citizen, ... you need to pay attention to him, take care of him and solve his problems" (Han Yanhong, "Sichuan People's Political Consultative Conference Vice-Chairman A Cheng said the Government should first treat monks as citizens," Lianhe zaobao, 9 March 2009).

33. "Preliminary investigations suggest that the killer might be an ethnic Tibetan, the inside source told China Daily, noting that a number of Tibetan separatists had sneaked into town from Chengdu and were attempting to stage a bombing in downtown Chongqing," Tan Yingzi and Hu Yinan, "Fingerprints retrieved from robber who shot sentry dead," China Daily, 23 March 2009 at http://www.chinadaily.com. cn/china/2009-03/23/content_7607576.htm. Chongqing has a population of 30 million. 
Nevertheless, the likely causes of the Tibetan unrest can be deduced from the main features of recent history. China occupied a largely unwilling and unfamiliar country that had litthe knowledge of it in 1950, imposed direct rule against popular wishes in 1959, and then, through collectivisation, the Cultural Revolution, and other persecution movements, squandered the dividend it had obtained from the peasant class by redistributing land. It created an even greater dividend in the early 1980s by permitting cultural, religious, and economic liberalisation and by promising a measure of autonomy, and then threw much of the goodwill this obtained by the gradual reintroduction in 1994, at the Third National Forum on Work in Tibet, of small but critical restrictions on culture and religion that Chinese officials believed necessary to stem the growing strains of nationalism among Tibetans. These restrictions included banning the worship and the display of photographs of the Dalai Lama, forcing "patriotic education" on monks and nuns, demanding that they denounce their religious teacher, banning government employees and students from any Buddhist practice, promoting all-out GDPexpansion instead of developing human capacity, supporting non-Tibetan migration of petty traders into Tibetan towns, and banning public discussion of these issues. ${ }^{(34)}$

From a statist point of view, these impositions appeared tolerable and necessary because they were accompanied by extensive investment in Tibetan towns and massive boosts in the wages of the small urban Tibetan middle-class, or at least those who worked in the government sector: the state had balanced coercion with emoluments. To Tibetans, both those in government jobs who benefited financially and those who lost out to migrants or to urban elites, the idea of trading cultural and religious entitlements for economic benefit may have seemed peculiar if not pernicious; it stretched tight the already taut bargain on which the contract with the state was based. In brief, the problem of the Communist Party in Tibet has always been that while it has proved itself capable of delivering material benefits to some sectors of the Tibetan population in return for absolute compliance, it has repeatedly followed the delivery of these goods with attempts to manage and reshape cultural and religious life.

This pattern of squandering political capital by interfering in cultural life recurred in late 2005 when a hard-line Chinese leader called Zhang Qingli was appointed as the Party Secretary of the TAR. His two predecessors had been relatively mild by local standards, and there was no obvious reason for an official of this type to be sent to Lhasa. His arrival coincided with a chain of renewed restrictions on culture and religion and an increase in policies that promoted migration of
non-Tibetans. In 2006 the state began a series of social engineering projects that unsettled social life: in the TAR the "comfortable housing project" forcibly moved at least a quarter of a million Tibetan farmers from their villages to new homes alongside major roads, while in eastern Tibet the "environmental migration" policy forced nomads to move to villages without any clear prospect of future income, obliged to abandon their animals and lifestyle. At the same time the authorities in the TAR rejected advice from local scholars to reintroduce restrictions on migration to compensate for the demographic impact of the opening of the Qinghai-Tibet railway in 2006.

By this time, the restrictions prescribed by the Third Forum in 1994 had already been extended from the TAR into eastern Tibetan areas, including patriotic education drives, bans on worship of the Dalai Lama, and restrictions on display of his photographs. Tibetans may or may not have overall political community of purpose, depending on whom one believes, but they certainly have common aspirations and values in terms of religion and culture, looking to Lhasa and the Dalai Lama as their cultural centre, and it was the views of these that Zhang and other officials appeared increasingly to be attacking. In these circumstances it is not surprising that criticism of Beijing spread across the plateau, reuniting groups that historically had differed politically but had strong cultural commonalities. Neither is it strange that some saw the Olympic year as a crucial, perhaps final, opportunity to push Beijing to change its policies before the Dalai Lama became too old to lead negotiations, should they be allowed. The monks who staged the first events on 10 March would hardly have needed any contact with any exiles to work out why that date offered an opportunity for them to try to get the attention of the leaders in Beijing rather than the satraps in Lhasa, at a moment when they rightly deduced that police would initially be under orders not to open fire or beat them publicly.

In the volatile climate that local policy-makers had created, any efforts of exile activists within Tibet would have been of secondary significance: the spreading of nationalism in Tibet was in large part a result of provocative policies by China such as its attacks on the Dalai Lama.

When unrest broke out in Lhasa on 14 March, the triggers for the subsequent events were probably technology, as in any modern society, not conspiracy: the news travelled instantly across the plateau because of images of the riot

34. See Robert Barnett with Mickey Spiegel, Cutting off the Serpent's Head: Tightening Control in Tibet, 1994-95, Human Rights Watch and Tibet Information Network, 1996. 
shown repeatedly on Chinese television, together with cellphone calls from relatives and friends in Lhasa and elsewhere. The violence and ethnic attacks in three of those protests dominated discussions by outsiders, but violence and unrest are likely outcomes in any city in the world where an indigenous majority sees abrupt and rapid immigration by other ethnic groups that it associates with marginalisation of its own interests and traditions. A violent outcome was more likely in Lhasa than in other cities of the world, since the local authorities had for decades outlawed any discussion of these demographic issues.

The consequence of protest has been in the short term costly - unknown deaths, innumerable arrests, military patrols in the streets of Tibetan quarters even in Chengdu, a closing of Tibet to foreigners and journalists, a decimating of monk numbers in the main monasteries, a political atmosphere that leads to increasing disenchantment among Tibetans with the Chinese state, a radicalisation of opinion among both $\mathrm{Ti}$ betan and Chinese nationalists, a collapse of talks between Beijing and the Dalai Lama, and damage to relations between China and other powers. These events continue the on-going pattern of resistance to Chinese efforts over a hundred years to impose direct rule over Tibetans instead of the relative success of its attempts at indirect governance through delegated authority. That resistance flares up particularly, and often violently, when direct rule by Beijing goes beyond political management to what are seen as arbitrary restrictions on religious and social practices. Until those issues are resolved, the questions about whether modern Chinese statebuilding can include those who are not ethnically Chinese, and whose primary allegiance may be to their nation rather than the state, are likely to remain unanswered. 